\title{
Neurochemical changes underlying schizophrenia-related behavior in a modified forced swim test in mice
}

\author{
Monika Woźniak ${ }^{\mathrm{a}}$, Paulina Cieślik ${ }^{\mathrm{a}}$, Marcin Marciniak ${ }^{\mathrm{a}}$, Tomasz Lenda ${ }^{\mathrm{a}}$, Andrzej Pilc ${ }^{\mathrm{a}, \mathrm{b}}$, \\ Joanna M. Wieronska ${ }^{\mathrm{a}, *}$ \\ a Institute of Pharmacology, Polish Academy of Sciences, 12 Smętna St, 31-343 Kraków, Poland \\ ${ }^{\mathrm{b}}$ Health Sciences Faculty, Institute of Public Health, Jagiellonian University Medical College, Kraków, Poland
}

\section{A R T I C L E I N F O}

\section{Keywords:}

Schizophrenia

GABAB

Negative symptoms

Animal models

Antipsychotic effect

Modified forced swim test

Western blotting

RT-PCR

\begin{abstract}
A B S T R A C T
The modified forced swim test (MFST) has excellent predictive validity for investigating the antipsychotic activity of drugs, with particular emphasis on their activity toward negative symptoms of schizophrenia. However, its face and construct validity are less understood. Therefore, in the present study, some biochemical changes within GABAergic and serotonergic neurotransmission that could be related to observed MK-801-induced disturbances and the activity of compounds active at those neurotransmitters were investigated.

In biochemical experiments, mice were treated acutely or chronically with MK-801 (13 days, $0.4 \mathrm{mg} / \mathrm{kg}$ ). Their brains were dissected and frontal cortices and hippocampi were taken for further analysis. The levels of neurotransmitters were investigated with HPLC, and the expression of surrogate markers of schizophrenia (5$\mathrm{HT}_{1 \mathrm{~A}}$ receptors, $\mathrm{GAD}_{65}$, and $\mathrm{GAD}_{67}$, at both protein and mRNA levels) was measured via western blotting and ${ }_{\mathrm{q}} \mathrm{RT}$-PCR. The modified forced swim test and locomotor activity were used to assess the activity of $\mathrm{GABA}_{\mathrm{B}}$ and 5$\mathrm{HT}_{1 \mathrm{~A}}$-related compounds.

Repeated MK-801 treatment (13 days, $0.4 \mathrm{mg} / \mathrm{kg}$ dose) led to decreases in the DOPAC/DA, 3MT/DA and HVA/DA metabolic ratios. Increased $5-\mathrm{HT}_{1 \mathrm{~A}}$ protein expression and decreased $\mathrm{GAD}_{65}$ and $\mathrm{GAD}_{67}$ protein expression was observed in both the cortex and hippocampus. mRNA levels for all proteins were decreased. The

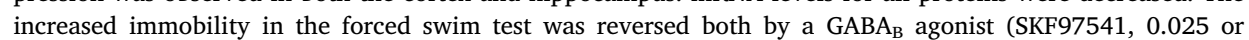
$0.05 \mathrm{mg} / \mathrm{kg}$ ), a positive allosteric modulator of $\mathrm{GABA}_{\mathrm{B}}$ receptor (racBHFF, 5 or $10 \mathrm{mg} / \mathrm{kg}$ ) and by a $5-\mathrm{HT}_{1 \mathrm{~A}}$ agonist $((R)-(+)-8$-OH-DPAT 0.01 or $0.025 \mathrm{mg} / \mathrm{kg})$.

Our research supports the hypothesis that changes in the levels of GABA and/or 5-HT $1 \mathrm{~A}$ receptors may contribute to the schizophrenia-like phenotype, and GABAergic and serotonergic agents may be good candidates for treating negative symptoms of schizophrenia.
\end{abstract}

\section{Introduction}

Schizophrenia is a mental disorder considered to be one of the most severe disabilities that affects $1 \%$ of the human population. The clinical picture of schizophrenia is complicated and involves many different symptoms that are divided into three groups: positive, negative and cognitive.

The background of schizophrenia inducement is not fully understood. Different trials, both in animal studies and in humans, have been undertaken to establish the neurochemical changes that contribute to schizophrenia development. Based on pharmacological observations, several theories have been proposed. One of the most common of these theories, which has dominated over the decades, is the dopaminergic theory of schizophrenia (Haracz, 1982; Heinz and Schlagenhauf, 2010; Munch-Petersen, 1955). The theory is based on the observations that dopaminomimetics, such as amphetamine, induce positive symptoms of schizophrenia in humans and, to a certain extent, in animal studies (hyperactivity, apomorphine-induced climbing). Following these observations, it was hypothesized that the increased dopamine outflow is responsible for at least certain schizophrenia symptoms, and

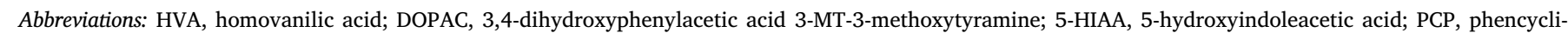

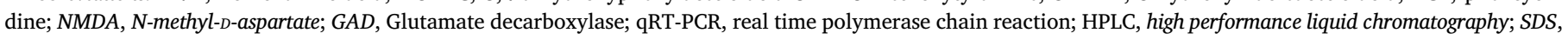
sodium dodecyl sulphate; GAPDH, glyceraldehyde 3-phosphate dehydrogenase

* Corresponding author.

E-mail address: wierons@if-pan.krakow.pl (J.M. Wieronska). 
consequently, the blockade of dopaminergic receptors could exert antipsychotic action.

The observations that NMDA receptor antagonists, such as PCP or MK-801, induce the full spectrum of schizophrenia symptoms in humans, including positive, negative and cognitive, stayed at the grounds of the glutamatergic theory of schizophrenia (Javitt, 1987). The theory is based on the assumption that the dysfunctional NMDA receptors are preferentially expressed on GABAergic interneurons in subcortical regions that innervate thalamocortical pyramidal neurons which, due to the loss of inhibitory control from interneurons, overactivate the other pyramidal neurons in the cortex (Conn et al., 2009; Moghaddam and Jackson, 2003).

Postmortem studies of schizophrenic patients' brains revealed that the changes in selected genes or proteins are typical for schizophrenia and are observed in the majority of schizophrenia cases, which are called the surrogate biomarkers of schizophrenia. The largest percentage of changes observed are for developmental/synaptic processes and the gamma aminobutyric acid system. The decreased levels of reelin, parvalbumin, $\mathrm{GAD}_{65}$ and $\mathrm{GAD}_{67}$ proteins and their mRNAs were consistently observed in the majority of postmortem schizophrenic brains (in the cortices and hippocampi) (Dracheva et al., 2004; Torrey et al., 2005; Thompson et al., 2011; Guidotti et al., 2000; Fatemi et al., 2005). On the basis of those observations, the theory was raised that the GABAergic dysfunction in schizophrenia is supposed to be a root of synaptic plasticity deficits and alteration of pyramidal neuron functioning (Conn et al., 2009; Moghaddam and Jackson, 2003). Concomitantly, the dysfunction of GABA synthesizing enzymes, $\mathrm{GAD}_{65}$ and $\mathrm{GAD}_{67}$, may be considered to be the liability factors underlying schizophrenia. In the other case, in certain schizophrenia patients, increased levels of 5-HT $1 \mathrm{~A}$ receptors were observed; however, the function of this receptor is linked predominantly with cognitive dysfunction.

The modified forced swim test is regarded as a test for the animal model of schizophrenia and is supposed to reflect depressive-like negative symptoms of the disease (Noda et al., 1995, 1997, 2000). The construct validity of the model is based on the chronic administration of NMDA antagonist, MK-801 (0.4 mg/kg; 13 days). The prolonged NMDA receptor blockade induces an increased time of immobility in the forced swim test, which is reversed by the administration of neuroleptics (Noda et al., 1995; Langen et al., 2012). The predictive validity of the model is well-established, as the administration of atypical antipsychotic drugs but no other drugs (antidepressants, anxiolytics) reverse the MK-801-induced behavioral changes. However, the neurochemical changes (i.e., face validity of the model) induced by chronic MK-801 administration have not been thoroughly characterized to date.

In the present study, we investigated chosen neurochemical changes underlying MK-801-induced behaviors observed in the modified forced swim test. We focused on those systems that are supposed to be responsible for schizophrenia development and that are also in the field of our interest, e.g., $\mathrm{GAD}_{65}, \mathrm{GAD}_{67}$ and $5-\mathrm{HT}_{1 \mathrm{~A}}$ proteins and their mRNAs levels. We used Western blotting techniques and qRT-PCR (real-time PCR) to investigate the levels of those proteins and their mRNAs. With the HPLC method, the levels of basal neurotransmitters were studied. Concomitantly, the GABAergic and serotonergic ligands were administered in order to confirm that the changes in those systems also underlie behavioral deficits observed in those animals.

\section{Materials and methods}

\subsection{Animals}

Male Albino Swiss (20-25g) mice (Charles River Laboratory, Sulzfeld, Germany) were used in all of the experiments. All animals were kept under a 12:12 light-dark cycle at room temperature of $19-21^{\circ} \mathrm{C}$ with free access to food and water. Each experimental group consisted of 8-10 animals per dose, and the animals were used only once in each test. All animals were experimentally naive prior to testing. The compounds were given in a volume of $10 \mathrm{ml} / \mathrm{kg}^{-1}$. The behavioral measurements were made by an observer unaware of the treatment. All procedures have been approved by the II Local Ethics Committee by the Institute of Pharmacology, Polish Academy of Sciences in Krakow. Both the animal facility conditions and the procedures are in accordance with EU Directive 2010/63/EU and subsequent ordinances of Polish Ministry of Agriculture and Rural Development.

\subsection{Drugs}

GABA $_{B}$ agonist SKF97541 (3-Aminopropyl(methyl)phosphinic acid), $\mathrm{GABA}_{\mathrm{B}}$ positive allosteric modulator rac-BHFF (5,7-Bis(1,1-dimethylethyl)-3-hydroxy-3(trifluoromethyl)-2(3H)-benzofuranone), $\mathrm{GABA}_{\mathrm{B}}$ antagonist CGP55845 ((2S)-3-[[(1S)-1-(3,4-Dichlorophenyl) ethyl]amino-2-hydroxypropyl](phenylmethyl)phosphinic acid hydrochloride), 5- $\mathrm{HT}_{1 \mathrm{~A}}$ agonist (RS)-8-OH-DPAT (2R)-(+)-8-Hydroxy-2-(di$n$-propylamino)tetralin hydrobromide, $5-\mathrm{HT}_{1 \mathrm{~A}}$ antagonist WAY100635 and NMDA antagonist MK-801 were purchased from Tocris, Bioscience, United Kingdom. SKF97541 and rac-BHFF were dissolved in EtOH $(200 \mu \mathrm{l})$ and then adjusted with $1 \%$ Tween-80 to $10 \mathrm{ml}$. (RS)-8-OHDPAT, WAY100635 ( $N$-[2-[4-(2-Methoxyphenyl)-1-piperazinyl] ethyl]$N$-2-pyridinylcyclohexanecarboxamide maleate), MK-801 $((5 S, 10 R)$ (+)-5-Methyl-10,11-dihydro-5H-dibenzo[a,d]cyclohepten-5,10-imine maleate) was dissolved in $0.9 \%$ saline. SKF97541 and racBHFF were administered intraperitoneally (i.p) $30 \mathrm{~min}$ before the test, and CGP55845 was administered 10 min before those drugs. WAY100635 $(0.1 \mathrm{mg} / \mathrm{kg}$, i.p) was given $45 \mathrm{~min}$ before the test and (RS)-8-OH-DPAT was administered subcutaneously (s.c) $15 \mathrm{~min}$ before the test. The control groups of animals were injected with appropriate vehicles. The schedule of administration and doses of drugs were adapted from our earlier studies. For WAY100635 and (RS)-8-OH-DPAT see the papers Woźniak et al., 2017; Wierońska et al., 2013, 2015a, and for $\mathrm{GABA}_{\mathrm{B}}$ ligands see the papers Wierońska et al., 2011, 2015b. The doses of racBHFF and SFF were partially taken from Gannon and Millan, 2011 or Frankowska et al., 2009, and were established experimentally.

\subsection{Determination of the neurotransmitter levels (HPLC)}

All measurements were performed with the use of the P680 HPLC system (Dionex, Sunnyvale, CA, USA) equipped with a Coulochem III electrochemical detector (model 5300, ESA Inc., Chelmsford, MA, USA), 5020 guard cell and 5010A analytical cell.

\subsubsection{Tissue preparation}

Tissue samples were weighed and homogenized in $1 \mathrm{ml}$ (frontal cortex) or $0.5 \mathrm{ml}$ (the whole hippocampus) ice-cold $0.1 \mathrm{M}$ perchloric acid containing $0.05 \mathrm{mM}$ ascorbic acid. After centrifugation $(10,000 \times g, 10 \mathrm{~min})$, the supernatants were filtered through $0.2-\mu \mathrm{m}$ cellulose filters (Alltech Associates Inc. Deerfield, IL, USA).

\subsubsection{NA, DA and 5-HT level measurements}

The tissue levels of NA, DA and the metabolites: homovanilic acid (HVA), 3,4-dihydroxyphenylacetic acid (DOPAC) and 3-methoxytyramine (3-MT), as well as 5-HT and its metabolite, 5-hydroxyindoleacetic acid (5-HIAA), were analyzed in $10 \mu \mathrm{l}$ of homogenate separated on $3 \times 100 \mathrm{~mm}$ Hypersil Gold-C18 analytical columns (Thermo Fisher Scientific Inc., Waltham, MA, USA). The mobile phase consisted of $50 \mathrm{mM}$ citrate-phosphate buffer pH 4.2, $0.25 \mathrm{mM}$ EDTA, $0.25 \mathrm{mM}$ sodium octyl sulfonate, $2.4 \%$ methanol and $1.3 \%$ acetonitrile. The flow rate was maintained at $0.7 \mathrm{ml} / \mathrm{min}$. The applied potential of a guard cell was $500 \mathrm{mV}$, while those of analytical cells were as follows: $\mathrm{E} 1=-50 \mathrm{mV}, \mathrm{E} 2=300 \mathrm{mV}$ with gain set at $100 \mathrm{nA}$.

\subsubsection{Data processing}

All data were collected, and chromatograms were integrated, with 
the use of Chromeleon 6.8 SP3 software. Neurotransmitter levels were quantified by peak area comparison with standards, as run on the day of analysis. The total rate of DA catabolism was calculated from the ratio of the final DA metabolite HVA to DA concentration and was expressed as the catabolic rate index $($ HVA/DA $) \times 100$. To assess participation of the MAO-dependent oxidative pathway of DA catabolism, the DOPACto-DA ratio was calculated and presented as an index of (DOPAC/ DA) $\times 100$. To assess participation of the COMT-dependent $O$-methylation in the DA turnover, the 3-MT-to-DA rate index was calculated (3MT/DA) $\times 100$. The total rate of 5 -HT catabolism was calculated from the concentration ratio of its metabolite 5-HIAA to 5-HT and was expressed as the catabolic rate index $(5-\mathrm{HIAA} / 5-\mathrm{HT}) \times 100$. All these indices were calculated using concentrations from individual tissue samples.

\subsection{Western blotting}

The mice were decapitated, their brains were removed and the frontal cortices and the whole hippocampi were dissected. The tissues were stored at $-80^{\circ} \mathrm{C}$ until Western blot analysis. Later, the tissues were homogenized in $2 \% \mathrm{SDS}$, denatured at $95^{\circ} \mathrm{C}$ for $10 \mathrm{~min}$ and centrifuged at $10,000 \mathrm{rpm}$ for $5 \mathrm{~min}$ at $4{ }^{\circ} \mathrm{C}$. The total protein concentration was quantified in the supernatant using a Pierce BCA Protein Assay Kit (Pierce Biotechnology, USA). The samples of protein were resolved on $10 \%$ SDS-polyacrylamide gels and transferred to nitrocellulose membranes with an electrophoretic transfer system (Bio-Rad, Poland). After that, the membranes were blocked for $60 \mathrm{~min}$ with blocking solution (mouse/rabbit chemiluminescence WB kit, Roche diagnostic, Germany), and then were incubated with primary antibodies against 5$\mathrm{HT}_{1 \mathrm{~A}}$ proteins on $48 \mathrm{kDa}$ (Abcam, 1:1000), $\mathrm{GAD}_{65}$ enzyme on $65 \mathrm{kDa}$ (Abcam, 1:1000), $\mathrm{GAD}_{67}$ enzyme on $67 \mathrm{kDa}$ (Abcam, 1:1000) and actin on $43 \mathrm{kDa}$ (1:5000, Sigma) as a standard. The blots were kept overnight at $4{ }^{\circ} \mathrm{C}$ with the appropriate primary antibodies. After that step, the blots were washed 3 times and incubated with secondary antibodies (anti-rabbit/anti-mouse) for $1 \mathrm{~h}$ at room temperature. The reactions were visualized by an enhanced chemiluminescence WB kit (mouse/ rabbit) (Roche diagnostic, Germany) and evaluated with a luminescent image analyzer (Fujifilm LAS-1000, Japan). The molecular weights of each protein band were calculated by Image Gauge software. The levels of assessed proteins were normalized to the actin band.

\subsection{Quantitative real-time PCR}

The level of mRNA expression for $5-\mathrm{HT}_{1 \mathrm{~A}}$ receptors, $\mathrm{GAD}_{65}$ and $\mathrm{GAD}_{67}$ enzymes in the frontal cortices and the whole hippocampi were dissected was measured. The analyses were performed on wild-type mice and on mice after chronic administration of MK-801 $(0.4 \mathrm{mg} / \mathrm{kg}$, 13 days). Total RNA from mouse tissue was extracted with Trizol reagent (Invitrogen, USA). The quantity of RNA was determined by OD measurement using a NanoDrop ND-1000 Spectrophotometer (Thermo Scientific, USA). Reverse transcription was applied with QuantiTect Reverse Transcription Kit (Qiagen, Germany). RNA sample ( $1 \mu \mathrm{g})$ was incubated in gDNA Wipeout Buffer at $42{ }^{\circ} \mathrm{C}$ for 2 min to remove contaminating genomic DNA. After that step, the reaction with reverse transcriptase was run at $42{ }^{\circ} \mathrm{C}$ for $15 \mathrm{~min}$ following its inactivation at $95^{\circ} \mathrm{C}$ for $3 \mathrm{~min}$. The specificity and efficiency for each primer set in PCR was determined using serially diluted gene-specific cDNA constructs. Optimized PCR was carried out in $15 \mu$ l of Power SYBR Green PCR Master Mix (Applied Biosystems, UK), forward and reverse primers (250 nM of each; Genomed, Poland) and tenfold diluted single-stranded cDNA on a CFX96 Touch real-Time PCR Detection System (Bio-Rad, Poland). Cycling conditions for 40 PCR cycles were as follows: denaturation for $15 \mathrm{~s}$ at $95^{\circ} \mathrm{C}$, annealing and extension for $60 \mathrm{~s}$ at $60{ }^{\circ} \mathrm{C}$. The relative expression of each gene was quantified using the comparative threshold cycle $\left(\Delta \Delta \mathrm{C}_{\mathrm{T}}\right)$ method after normalizing to GAPDH as described in detail by Livak and Schmittgen (2001).
A

Frontal cortex

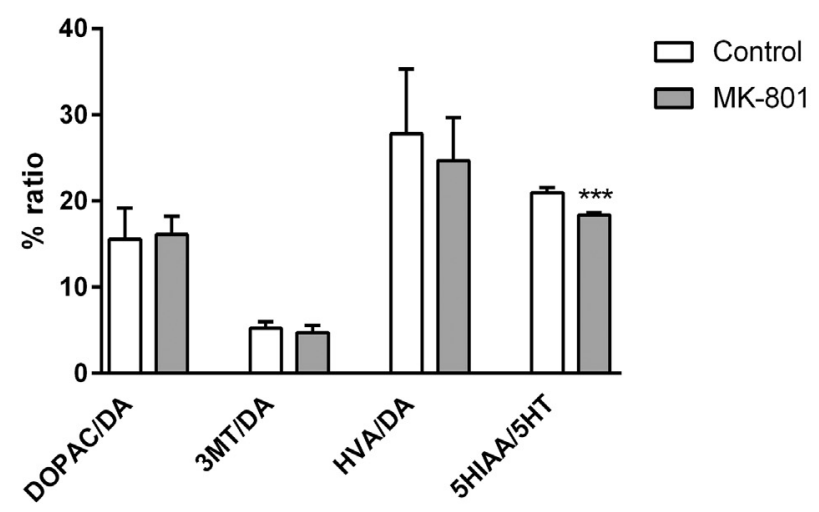

B

Hippocampus

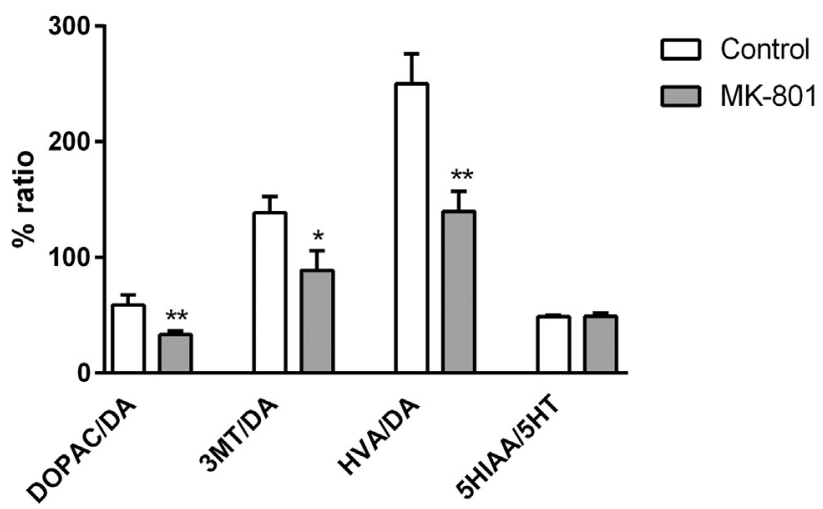

Fig. 1. The effect of chronic (13 days) MK- $801(0.4 \mathrm{mg} / \mathrm{kg})$ administration on the metabolic ratios in frontal cortex (A) and hippocampus (B) of mice. $\mathrm{n}=9-10$ for each group. ${ }^{*} \mathrm{P}<0.05{ }^{* *} \mathrm{P}<0.01$ and ${ }^{* * *} \mathrm{P}<0.001$ compared to controls.

\subsection{Modified forced swim test}

For the forced swim test, a glass cylinder containing $11 \mathrm{~cm}$ of water at a temperature of 23 to $26^{\circ} \mathrm{C}$ (height, $20 \mathrm{~cm}$; internal diameter, $15 \mathrm{~cm}$ ) was used. On day 0 of the experiment, the mice were forced to swim in the water for $3 \mathrm{~min}$, and the immobility time was recorded during the whole 3-min period. Afterwards, animals were removed from the water, dried with a paper towel and put under infrared light. Starting the following day, mice were treated with $0.4 \mathrm{mg} / \mathrm{kg}$ MK801 i.p. once daily for 13 days. The control animals were treated with saline. After the 13th day of MK-801 administration, the animals had a 1-day washout period. On day 15th of the experiment, a second swim test was performed according to the procedure described above. During this second swim test, compounds or vehicles were administered. The immobility time induced by MK-801 was measured in the second trial of the forced swim test. The total immobility time was measured as a difference between the second and first immobility time of swimming (T2-T1).

\subsection{Locomotor activity}

The next day after the swimming test, the locomotor activity was reordered individually for each mouse in OPTO-M3 locomotor activity 
A
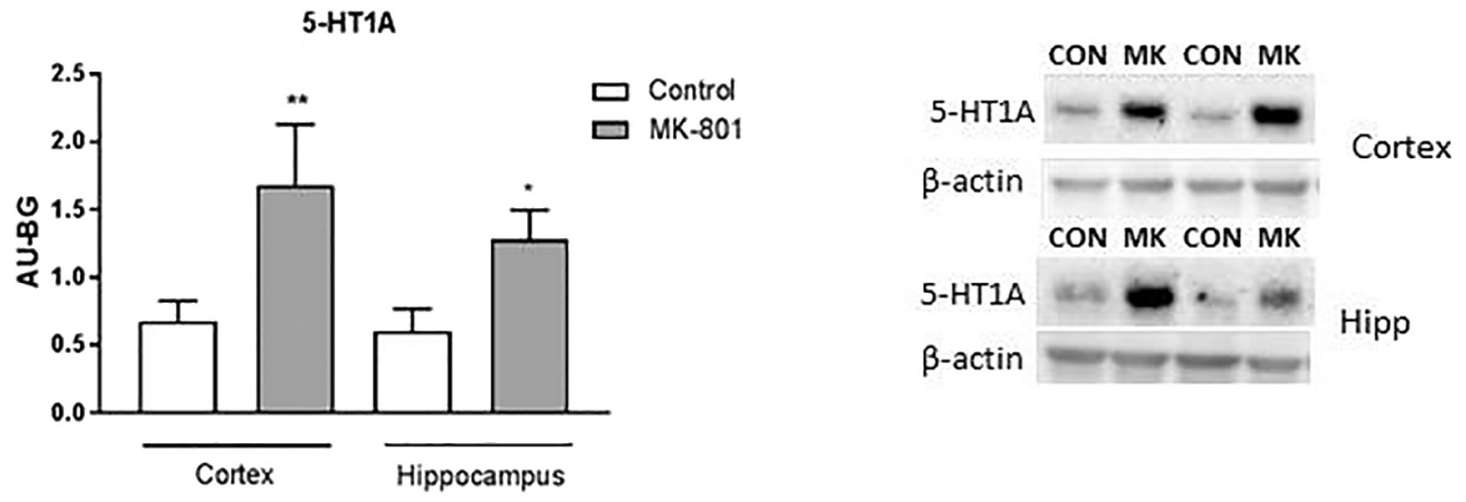

B
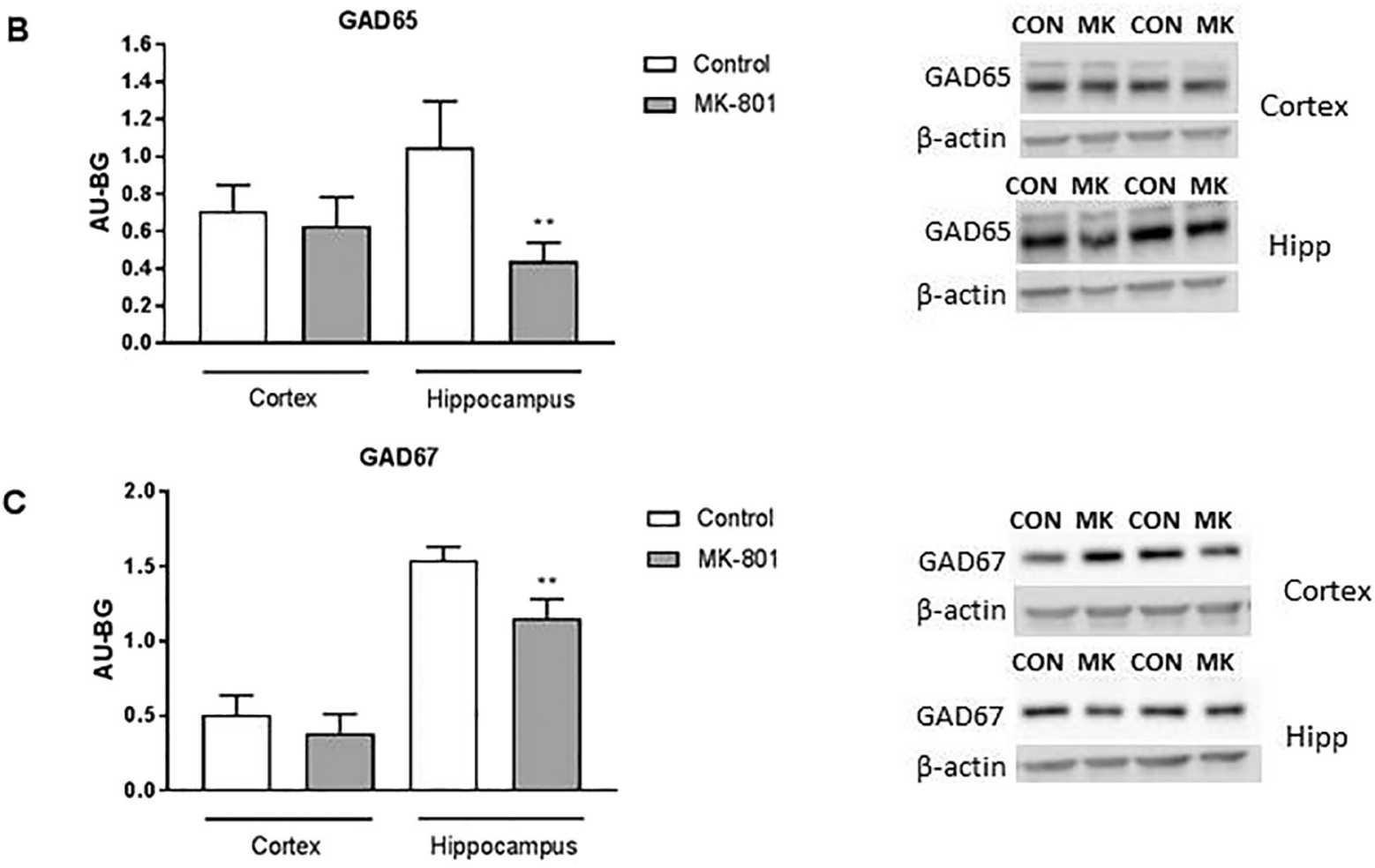

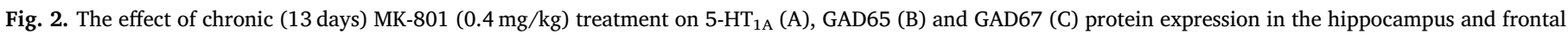

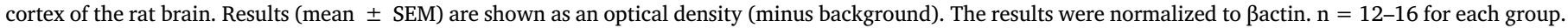
${ }^{*} \mathrm{P}<0.02$ and ${ }^{*} \mathrm{P}<0.04$ compared to controls.

cages (size: $13 \times 23 \times 15 \mathrm{~cm}$, Columbus Instrument), which defined the total ambulation scores within a $10 \mathrm{~min}$ test. The locomotor activity was measured as a control experiment for the studies on the modified forced swim test. For this procedure the investigated compounds were administered once again at the same schedule as for MFST.

\subsection{Statistical analysis}

The data are presented as the means \pm S.E.M. The statistical analysis of data was performed by GraphPad Prism and Statistica 10 program. A P value $<0.05$ was considered to be statistically significant. The exact statistical analysis is described in the relevant results section.

\section{Results}

\subsection{Changes in neurotransmitter levels in $M K-801$ treated mice}

No statistically significant changes were observed between controls and acutely or chronically treated MK-801 animals in the levels of monoamines (noradrenaline, dopamine and serotonin, data not shown) and amino acids (glutamate, GABA). When the metabolite ratios were compared in animals chronically treated with MK-801, 5HIAA/5-HT ratio was decreased in the cortex $(\mathrm{P}<0.001, t=4.018, \mathrm{df}=15)$ and significantly decreased DOPAC/DA $(\mathrm{P}<0.01, t=2.624, \mathrm{df}=17)$, 3MT/DA $(\mathrm{P}<0.05 ; t=2.263, \mathrm{df}=17)$, and HVA/DA $(\mathrm{P}<0.01$, $t=3.482, \mathrm{df}=17$ ) were observed in the hippocampus but not in the frontal cortex (Fig. 1A, B). Also, no changes in the 5HIAA/5HT ratio were observed.

\subsection{Changes in $5-H T_{1 A}, G A D_{65}$ and $G A D_{67}$ protein expression in $M K-801-$ treated mice}

There were no statistically significant changes in $5-\mathrm{HT}_{1 \mathrm{~A}}, \mathrm{GAD}_{65}$ or $\mathrm{GAD}_{67}$ proteins levels between controls and mice after single MK-801 administration either in the frontal cortex or in the hippocampus (data not shown).

$t$-Test analysis revealed that chronic MK-801 administration induced increases in $5-\mathrm{HT}_{1 \mathrm{~A}}$ protein levels in both the cortex $(\mathrm{P}<0.02$, 
A

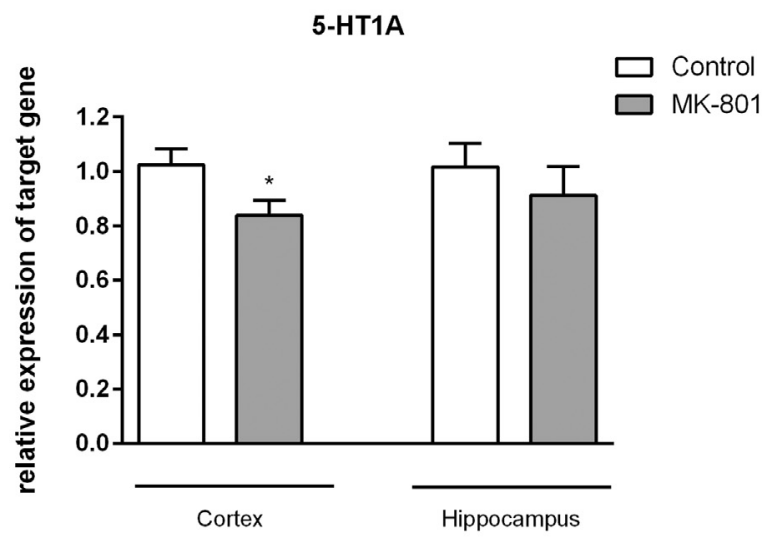

GAD65

B
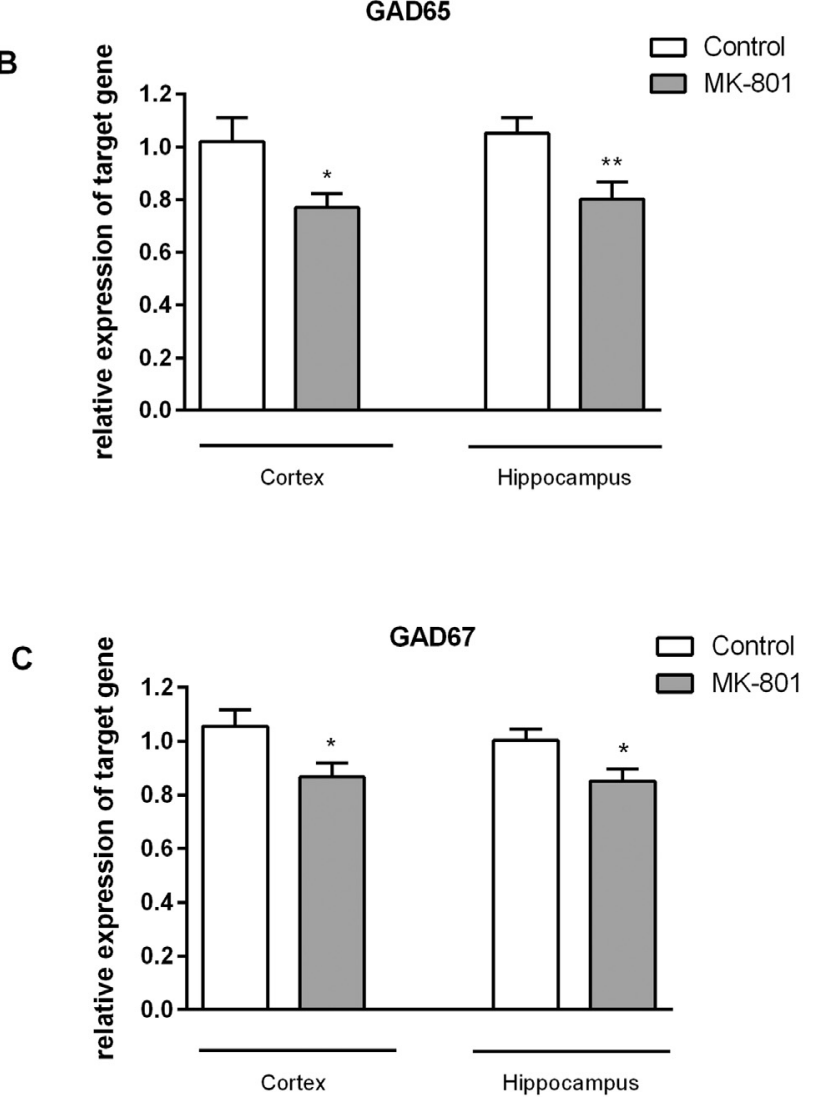

Fig. 3. The effect of chronic (13 days) MK- $801(0.4 \mathrm{mg} / \mathrm{kg})$ treatment on 5 $\mathrm{HT}_{1 \mathrm{~A}}$ (A), GAD65 (B) and GAD67 (C) mRNA expression in the hippocampus and frontal cortex of the rat brain. Results (mean \pm SEM) are shown as relative expression of target gene. $n=6$ for each group. ${ }^{*} \mathrm{P}<0.02$ and ${ }^{*} \mathrm{P}<0.04$ compared to controls.

$t=2.099, \mathrm{df}=24)$ and in the hippocampus $(\mathrm{P}<0.04, t=2.402$, $\mathrm{df}=20$ ) (Fig. 2A). The t-test revealed that the $G A D_{65}$ and $\mathrm{GAD}_{67}$ protein levels were significantly lower in the hippocampi of MK-801-administered mice than in the control mice, $\mathrm{P}<0.02(t=2.35, \mathrm{df}=27)$ and $\mathrm{P}<0.02(t=2.39, \mathrm{df}=27)$, respectively (Fig. $2 \mathrm{~B}, \mathrm{C})$.

3.3. Changes in $5-H T_{1 A}, G A D_{65}$ and $G A D_{67}$ gene expression levels in $M K-$ 801-treated mice

There were no statistically significant changes in $5-\mathrm{HT}_{1 \mathrm{~A}}, \mathrm{GAD}_{65}$ or $\mathrm{GAD}_{67}$ gene expression between controls and mice after single MK-801 administration either in the frontal cortex or in the hippocampus (data not shown).

In mice chronically treated with MK-801, lower expression of 5$\mathrm{HT}_{1 \mathrm{~A}}$ gene expression in the cortex was observed ( $t$-test analysis: $t=2.52$, df $=10, \mathrm{P}<0.04)($ Fig. $3 \mathrm{~A}) . G A D_{65}$ and $G A D_{67}$ gene expression levels were significantly lower in both the cortices $(\mathrm{P}<0.04$, $t=2.379, \mathrm{df}=10$ and $\mathrm{P}<0.04, t=2.33, \mathrm{df}=10$, respectively) and hippocampi $(\mathrm{P}<0.01, t=2.848, \mathrm{df}=10$ and $\mathrm{P}<0.04, t=2.45$, $\mathrm{df}=10$, respectively) of MK-801-administered mice compared to control mice (Fig. 3B, C).

3.4. Effect of administration of the $G A B A_{B}$ agonist, $S K F 97541$, and $G A B A_{B}$ positive allosteric modulator, racBHFF, in the modified forced swim test in mice

Chronic MK-801 administration ( $0.4 \mathrm{mg} / \mathrm{kg}$, i.p, 13 days) induced an increase in the immobility time measured in the time of $3 \mathrm{~min}$ (P < 0.001). One-way ANOVA followed by Newman-Keuls post hoc comparison revealed that the acute administration of SKF97541 in two doses, 0.025 and $0.05 \mathrm{mg} / \mathrm{kg}$, significantly decreased the MK-801-induced increase in immobility time $\left[\mathrm{F}_{(3.35)}=3.95 ; \mathrm{P}<0.05\right]$ (Fig. 4A). The dose of $0.01 \mathrm{mg} / \mathrm{kg}$ was ineffective. Spontaneous locomotor activity was not changed in all groups of animals (Fig. 4B). The administration of racBHFF also decreased the prolonged immobility time in the doses, 5 and $10 \mathrm{mg} / \mathrm{kg}\left[\mathrm{F}_{(3.36)}=7.7 ; \mathrm{P}<0.01\right]$ (Fig. 5A). Spontaneous locomotor activity was not changed (Fig. 5B).

The administration of $\mathrm{GABA}_{\mathrm{B}}$ antagonist, CGP55845, $10 \mathrm{~min}$ before SKF97541 or racBHFF reversed the antipsychotic-like effects observed (Fig. 4A). The combinations had no effect on spontaneous locomotor activity (Fig. 5A).

3.5. Effect of the administration of the 5-HT $T_{1 A}$ agonist, (RS)-8-OH-DPAT, in the modified forced swim test in mice

Chronic MK-801 administration ( $0.4 \mathrm{mg} / \mathrm{kg}$, i.p, 13 days) induced an increase in the immobility time measured in the time of $3 \mathrm{~min}$ $(\mathrm{P}<0.001)$. One-way ANOVA followed by the Newman-Keuls post hoc comparison revealed that the acute administration of $(R S)-8-\mathrm{OH}-$ DPAT in the doses, 0.01 and $0.025 \mathrm{mg} / \mathrm{kg}$, significantly decreased the MK-801-induced increase in immobility time $\left[F_{(3.35)}=6.85\right.$; $\mathrm{P}<0.0009$ ] (Fig. 6A). Spontaneous locomotor activity was not changed in all groups of animals (Fig. 6B).

The administration of $5-\mathrm{HT}_{1 \mathrm{~A}}$ antagonist, WAY100635, $30 \mathrm{~min}$ before $(R S)$-8-OH-DPAT reversed the antipsychotic-like-effects observed (Fig. 6A). The combinations had no effects on spontaneous locomotor activity (Fig. 6B).

\section{Discussion}

The modified forced swim test is considered to be a model for depressive-like negative symptoms of schizophrenia and has a high predictive validity in antipsychotic-drug discovery. The model was introduced in 1995 by Noda et al. (1995), and initially, it was based on the chronic administration of PCP (Noda et al., 1995; Noda et al., 2000), but subsequently, it was shown that not only PCP (which is called a "dirty drug") but also a non-competitive NMDA antagonist, MK-801, may induce the behavioral paradigm similar to that observed after PCP administration (Langen et al., 2012; Wierońska et al., 2015a, 2015b).

In the present paper, neurochemical changes underlying chronic MK-801 administration were examined, and subsequently, the activity of serotonergic and GABAergic agents in the modified forced swim test were investigated.

The observed behavioral changes (i.e., prolonged immobility time induced by chronic MK-801 administration) did not develop after single MK-801 administration. This phenomenon may be considered unique because in the majority of tests detecting antipsychotic efficacy of 
A

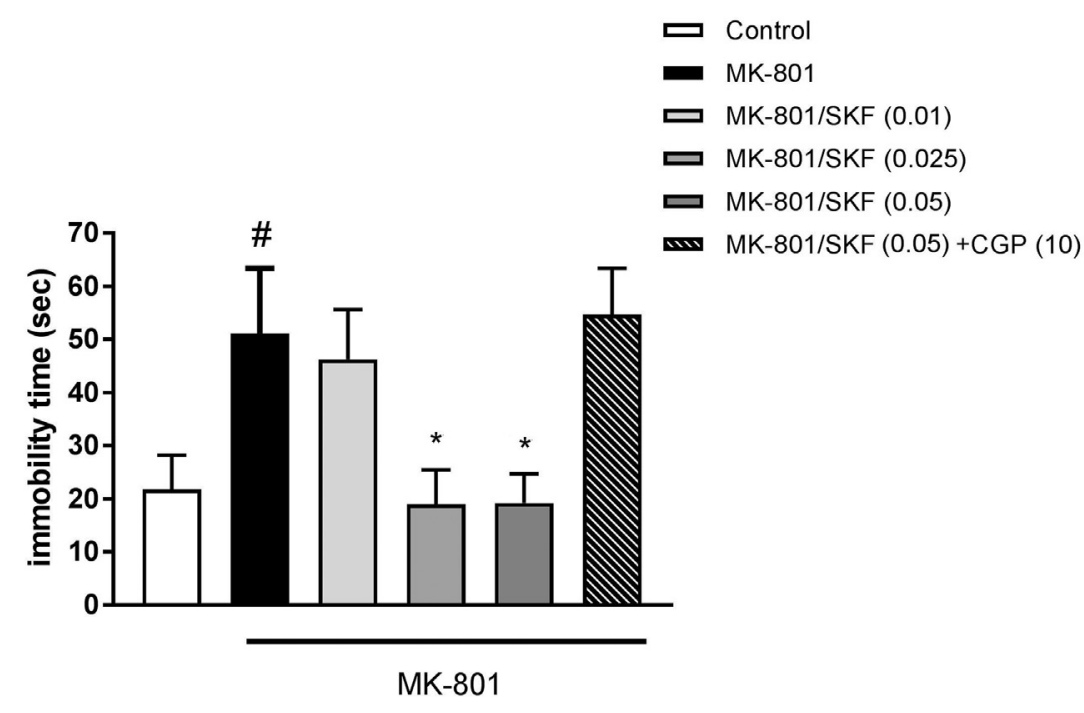

B

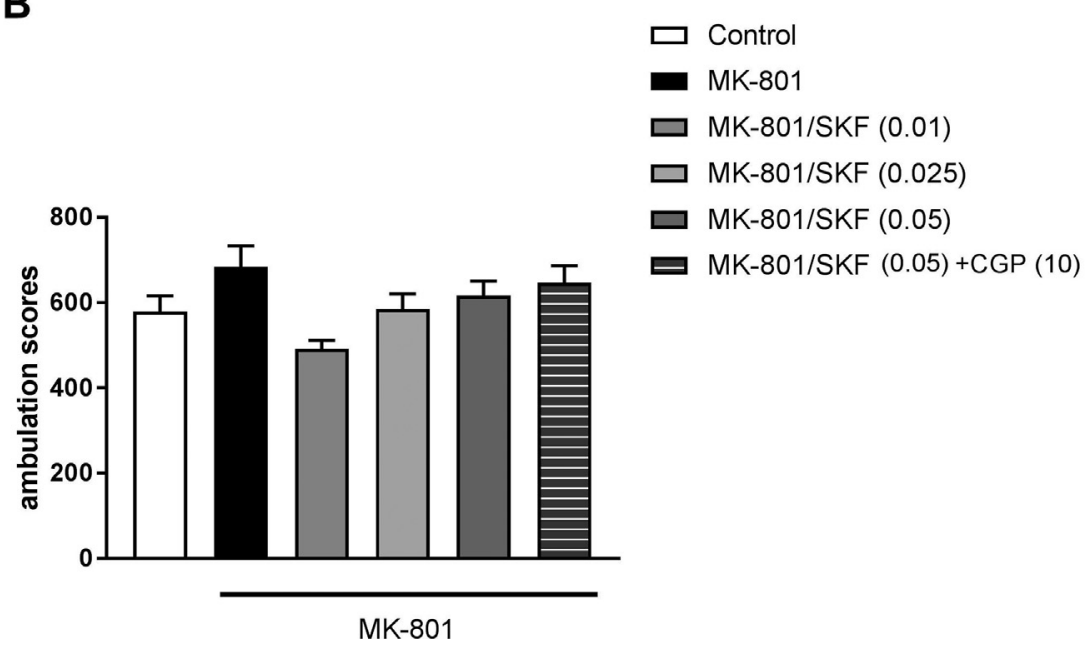

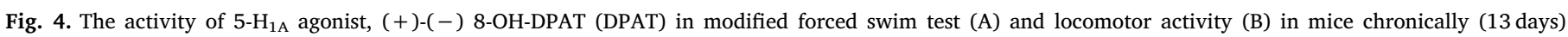

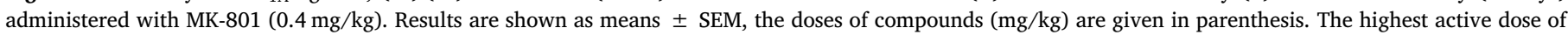

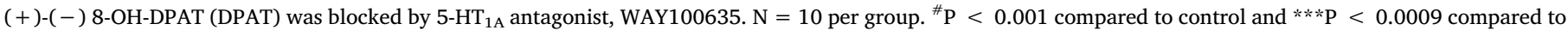
MK-801-treated mice.

drugs, for example, MK-801-induced hyperactivity, single MK-801 administration is sufficient to induce behavioral disruptions reversed by antipsychotics (Wierońska et al., 2015a, 2015b; Woźniak et al., 2016; Woźniak et al., 2017). However, those behavioral disturbances are based on the rapid action of MK-801 that induces transient neurochemical changes not detected in the present study. However, in our previous experiments, it was shown with in vivo microdialysis experiments that single MK-801 administration induced increases in the release of several neurotransmitters, including glutamate, dopamine, serotonin and GABA (Wierońska et al., 2015a, 2015b; Woźniak et al., 2017). In this study, with the use of HPLC, no changes in neurotransmitter levels were observed after single MK-801 administration. Additionally, there were no changes in neurotransmitter levels in mice chronically administered with MK-801, but decreased ratios of DOPAC/ DA, 3MT/DA and HVA/DA were observed, which suggests that the activity of enzymes catabolizing dopamine metabolism is decreased in those animals. In general, dopaminergic innervation of hippocampus is sparse, what translates to very low tissue levels of dopamine (approx. $10 \mathrm{pg} / \mathrm{mg}$ wet tissue vs. $10,000 \mathrm{pg} / \mathrm{mg}$ in the striatum or $1000 \mathrm{pg}$ in the substantia nigra or cortex). According to literature hippocampal dopamine is responsible for promoting attention, episodic memory formation, spatial learning, and synaptic plasticity. It is believed that dopaminergic innervation of the hippocampus has its source in VTA (Gasbarri et al., 1994, 1997; Bethus et al., 2010).

This finding may indicate that chronic blockade of the NMDA receptor induces the opposite effect on dopaminergic neurotransmission than single MK-801 administration and would be in line with behavioral observations, in which no changes in locomotor activity after 13 days of administration were observed (with one-day wash out break), although the changes in the other tests, including the modified forced swim test, are observed up to one week after cessation of the treatment (Qiao et al., 2001; Paine and Carlezon, 2009).

Subsequently, several factors that were reported to be important in schizophrenia development and treatment, such as $\mathrm{GAD}_{65}, \mathrm{GAD}_{67}$ proteins and $5-\mathrm{HT}_{1 \mathrm{~A}}$ receptors, were investigated by qRT-PCR and Western blot techniques. $\mathrm{GAD}_{65}$ and $\mathrm{GAD}_{67}$ proteins and, to a lesser extent, $5-\mathrm{HT}_{1 \mathrm{~A}}$ receptors are regarded as putative biomarkers of schizophrenia. As in postmortem studies, decreases in GAD proteins and the 


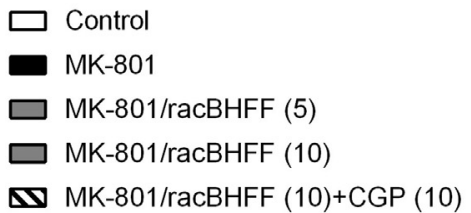

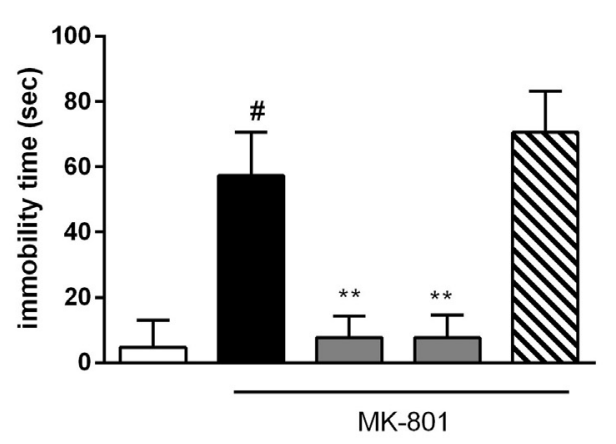

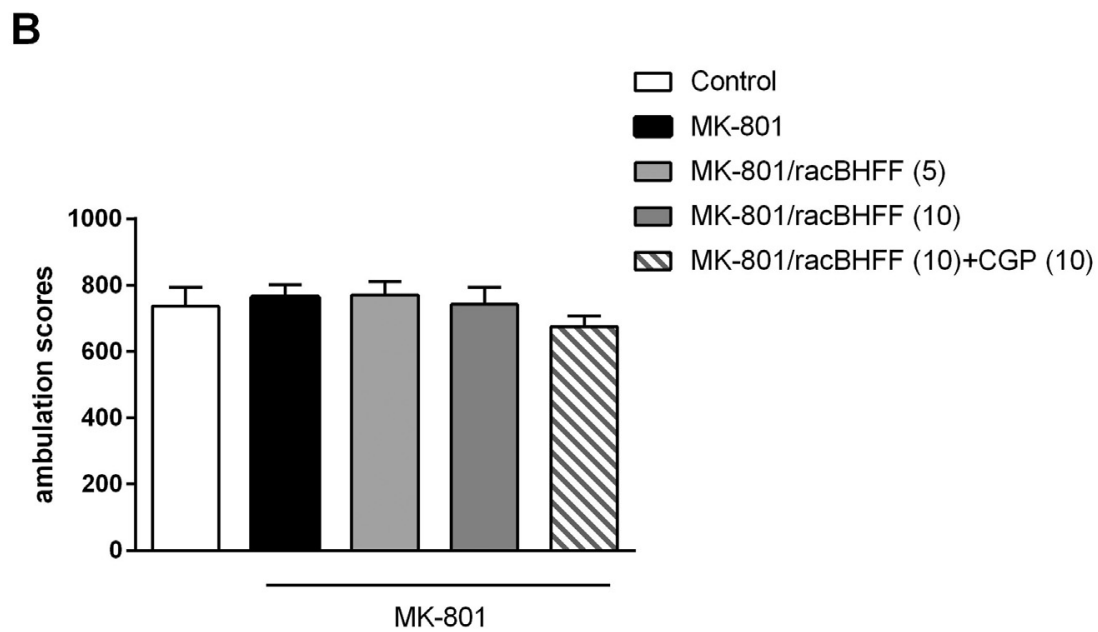

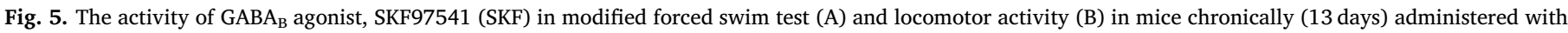

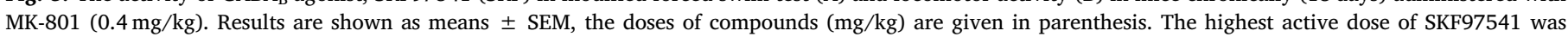
blocked by $\mathrm{GABA}_{\mathrm{B}}$ antagonist, CGP55845. ${ }^{*} \mathrm{P}<0.001$ compared to control and ${ }^{*} \mathrm{P}<0.05$ compared to MK-801-treated mice.

up-regulation of $5-\mathrm{HT}_{1 \mathrm{~A}}$ receptors in schizophrenia patients were observed (Guidotti et al., 2000; Fatemi et al., 2005; Gurevich and Joyce, 1997; Sumiyoshi et al., 1996; Hashimoto et al., 1993). Therefore, the changes in the expression of those proteins may indicate increased susceptibility of individuals to develop schizophrenia. However, the results concerning $5-\mathrm{HT}_{1 \mathrm{~A}}$ receptors are inconsistent, and although the majority of studies indicate an increase of $5-\mathrm{HT}_{1 \mathrm{~A}}$ binding (Gurevich and Joyce, 1997; Sumiyoshi et al., 1996; Hashimoto et al., 1993), several reports show their decrease, as well (Gray et al., 2006).

In the present study, the 13 days of chronic administration of NMDA antagonist, MK-801 (0.4 mg/kg, i.p) resulted in the up-regulation of 5$\mathrm{HT}_{1 \mathrm{~A}}$ receptors in both the cortex and hippocampus and decreased expression of $\mathrm{GAD}_{65}$ and $\mathrm{GAD}_{67}$ proteins only in the hippocampus. No changes in the level of GADs were observed in the cortex. mRNA analysis revealed that grm5-HT $1 \mathrm{~A}$ was decreased in the cortex. Both $\mathrm{GAD}_{65}$ mRNA and $\mathrm{GAD}_{67}$ mRNA levels were decreased in both investigated structures, compared to control animals. Therefore, our results partially confirm that the pro-psychotic behavior observed after prolonged MK801 administration may be a result of the dysfunction in serotonergic and GABAergic signaling, resembling the changes observed in schizophrenic patients.

The modified forced swim test described in this study is regarded as the model of depressive-like negative symptoms of schizophrenia, which are treatment-resistant in humans. Typical neuroleptics are not effective in those patients; positive results may be observed after atypical antipsychotic drug treatment (risperidone, lurasidone), although not in all patients (Samara et al., 2016). Therefore, new strategies are needed to find more promising targets than the presently used medications. It seems that GABAergic and serotonergic neurotransmission may be targets of antipsychotic medication focused on the treatment of negative symptoms. Therefore, in the second part of this study, the GABAergic and serotonergic ligands were administered to confirm that the reversal of MK-801-induced prolongation of the immobility time can be achieved through targeting those two neurotransmitters via metabotropic receptors. We used several ligands activating $\mathrm{GABA}_{\mathrm{B}}$ and $5-\mathrm{HT}_{1 \mathrm{~A}}$ receptors, such as racBHFF, SKF97541 and $(+)(-) 8-\mathrm{OH}-$ DPAT. RacBHFF is a positive allosteric modulator of the $\mathrm{GABA}_{\mathrm{B}}$ receptor and increases the affinity of GABA to its binding site (Malherbe et al., 2008), while SKF97541 is a very potent $\mathrm{GABA}_{\mathrm{B}}$ agonist, at least ten times more active than baclofen (Froestl et al., 1995). Both compounds antagonized MK-801-induced increased immobility without affecting spontaneous locomotor activity. The effects of compounds were blocked by the administration of GABA ${ }_{B}$ antagonist, CGP55845. In parallel, selective $5-\mathrm{HT}_{1 \mathrm{~A}}$ agonist, $(R)-(+)$-8-hydroxy-DPAT hydrobromide, was investigated (Cornfield et al., 1991), which is an enantiomer of 8-hydroxy-DPAT hydrobromide, a very potent 5 - $\mathrm{HT}_{1 \mathrm{~A}}$ agonist. The compound reversed MK-801-induced behavioral deficits also without affecting spontaneous locomotor activity. This effect was blocked by $5-\mathrm{HT}_{1 \mathrm{~A}}$ antagonist administration of WAY100635.

The results obtained in the present paper are in line with our recently published papers in which it was shown that $\mathrm{GABA}_{\mathrm{B}}$ and $5-\mathrm{HT}_{1 \mathrm{~A}}$ receptors are involved in reversing MK-801-induced effects, mainly 


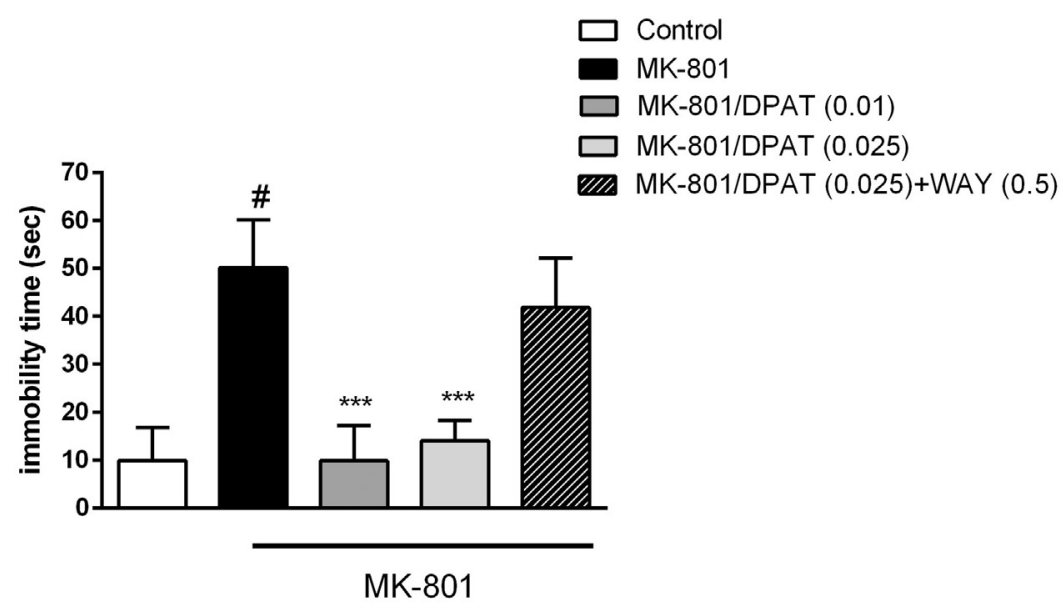

B

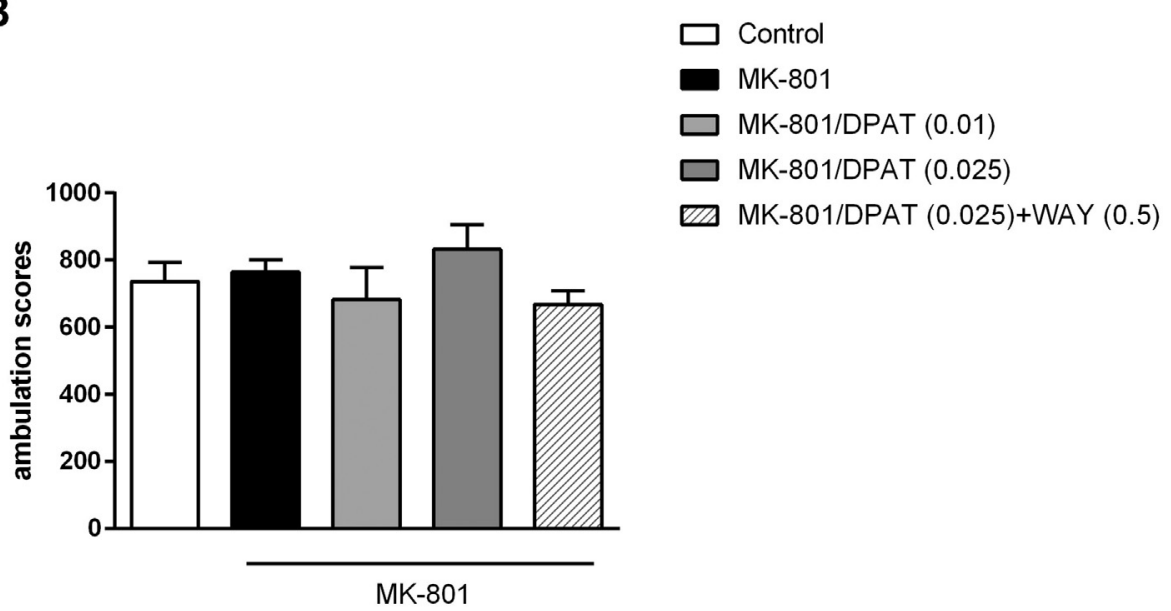

Fig. 6. The activity of $\mathrm{GABA}_{\mathrm{B}}$ PAM, racBHFF in modified forced swim test (A) and locomotor activity (B) in mice chronically (13 days) administered with MK-801 $(0.4 \mathrm{mg} / \mathrm{kg})$. Results are shown as means \pm SEM, the doses of compounds $(\mathrm{mg} / \mathrm{kg})$ are given in parenthesis. The highest active dose of $(+)-(-)) 8-\mathrm{OH}-\mathrm{DPAT}(\mathrm{DPAT})$ was blocked by GABA ${ }_{B}$ antagonist, CGP55845. ${ }^{*} \mathrm{P}<0.001$ compared to control and ${ }^{* *} \mathrm{P}<0.01$ compared to MK-801-treated mice.

after acute MK-801 administration (Wierońska et al., 2015a, 2015b; Woźniak et al., 2016). However, $\mathrm{GABA}_{\mathrm{B}}$ receptor activators used here (SKF97541 and racBHFF), as well as the 5 - $\mathrm{HT}_{1 \mathrm{~A}}$ agonist, $(R)-(+)-8-\mathrm{OH}-$ DPAT, were not investigated in MFST after chronic MK-801 administration. If the administration of the compounds would reverse the changes in hippocampal dopamine and associated metabolites, GADs enzymes and $5-\mathrm{HT}_{1 \mathrm{~A}}$ receptors remains to be establish. However, 13 days of MK-801 administration were needed to detect neurochemical changes that were not observed after single administration. The reversal of those changes was observed after acute administration of the investigated compounds. Therefore, our working hypothesis is that the reversal of observed behavioral deficit is rather related to direct activation of $\mathrm{GABA}_{\mathrm{B}}$ or $5-\mathrm{HT}_{1 \mathrm{~A}}$ receptors (which are inhibitory receptors linked to Gi proteins (Bockaert et al., 2010)) and subsequent cascade of transitional changes in the activity of neurons by which they are expressed (e.g. glutamatergic neurons in the hippocampus (Tokarski et al., 2002)).

Taken together, our results are the first to demonstrate that certain neurochemical changes that underlie animals' behavior related to schizophrenia are similar to those observed in schizophrenic patients. Therefore, it may be concluded that the changes in surrogate markers of schizophrenia susceptibility may be observed as a result of prolonged hypofunction of NMDA receptors. This study's results indicate and indirectly confirm that the hypofunction of NMDA receptors may lead to decreased levels of the enzymes responsible for GABA synthesis and to up-regulation of 5- $\mathrm{HT}_{1 \mathrm{~A}}$ receptors. Therefore, the model based on the chronic administration of MK-801 possesses not only good predictive validity, which is the most important factor in drug discovery, but its construct validity is also better than that of the single administration of MK-801. GABAergic and serotonergic agents, acting via $\mathrm{GABA}_{\mathrm{B}}$ and 5$\mathrm{HT}_{1 \mathrm{~A}}$ receptors, are good candidates to be effective drugs in the treatment of the negative symptoms of schizophrenia.

\section{Acknowledgements}

This work was supported by grant no 2015/17/B/NZ7/02984 (OPUS) from the National Science Center (NCN) in Poland to J. M. Wierońska and Statutory Funds of Institute of Pharmacology PAS in Kraków.

The authors have no conflicts of interest to disclose.

\section{References}

Bethus, I., Tse, D., Morris, R.G., 2010. Dopamine and memory: modulation of the persistence of memory for novel hippocampal NMDA receptor-dependent paired associates. J. Neurosci. 30 (5), 1610-1618.

Bockaert, J., Perroy, J., Bécamel, C., Marin, P., Fagni, L., 2010. 2010. GPCR interacting 
proteins (GIPs) in the nervous system: roles in physiology and pathologies. Annu. Rev. Pharmacol. Toxicol. 50, 89-109.

Conn, J., Lindsley, C., Jones, C., 2009. Activation of metabotropic glutamate receptors as a novel approach for the treatment of schizophrenia. Trends Pharmacol. Sci. 30 (1), $25-31$.

Cornfield, L.J., Lambert, G., Arvidsson, L.E., Mellin, C., Vallgårda, J., Hacksell, U., Nelson, D.L., 1991. Intrinsic activity of enantiomers of 8-hydroxy-2-(di-n-propylamino)tetralin and its analogs at 5-hydroxytryptamine1 $\mathrm{A}$ receptors that are negatively coupled to adenylate cyclase. Mol. Pharmacol. 39 (6), 780-787.

Dracheva, S., Elhakem, S.L., Mcgurk, S.R., Davis, K.L., Haroutunian, V., 2004. GAD67 and GAD65 mRNA and protein expression in cerebrocortical regions of elderly patients with schizophrenia. J. Neurosci. Res. 76 (4), 581-592.

Fatemi, S.H., Stary, J.M., Earle, J.A., Araghi-Niknam, M., Eagan, E., 2005. GABAergic dysfunction in schizophrenia and mood disorders as reflected by decreased levels of glutamic acid decarboxylase 65 and $67 \mathrm{kDa}$ and Reelin proteins in cerebellum. Schizophr. Res. 72 (2-3), 109-122.

Frankowska, M., Nowak, E., Filip, M., 2009. Effects of GABAB receptor agonists on cocaine hyperlocomotor and sensitizing effects in rats. Pharmacol. Rep. 61 (6), 1042-1049.

Froestl, W., Mickel, S.J., Hall, R.G., von Sprecher, G., Strub, D., Baumann, P.A., Brugger, F., Gentsch, C., Jaekel, J., Olpe, H.R., 1995. Phosphinic acid analogues of GABA. 1. New potent and selective GABAB agonists. J. Med. Chem. 38 (17), 3297-3312.

Gannon, R.L., Millan, M.J., 2011. Positive allosteric modulators at GABAB receptors exert intrinsic actions and enhance the influence of baclofen on light-induced phase shifts of hamster circadian activity rhythms. Pharmacol. Biochem. Behav. 99 (4), 712-717.

Gasbarri, A., Verney, C., Innocenzi, R., Campana, E., Pacitti, C., 1994. Mesolimbic dopaminergic neurons innervating the hippocampal formation in the rat: a combined retrograde tracing and immunohistochemical study. Brain Res. 668 (1-2), 71-79.

Gasbarri, A., Sulli, A., Packard, M.G., 1997. The dopaminergic mesencephalic projections to the hippocampal formation in the rat. Prog. Neuro-Psychopharmacol. Biol. Psychiatry 21 (1), 1-22.

Gray, L., Scarr, E., Dean, B., 2006. Serotonin 1a receptor and associated G-protein activation in schizophrenia and bipolar disorder. Psychiatry Res. 143 (2-3), 111-120.

Guidotti, A., Auta, J., Davis, J.M., Di-Giorgi-Gerevini, V., Dwivedi, Y., Grayson, D.R Impagnatiello, F., Pandey, G., Pesold, C., Sharma, R., Uzunov, D., Costa, E., 2000. Decrease in reelin and glutamic acid decarboxylase67 (GAD67) expression in schizophrenia and bipolar disorder: a postmortem brain study. Arch. Gen. Psychiatry 57 (11), 1061-1069.

Gurevich, E.V., Joyce, J.N., 1997. Alterations in the cortical serotonergic system in schizophrenia: a postmortem study. Biol. Psychiatry 42 (7), 529-545.

Haracz, L., 1982. The dopamine hypothesis - an overview of studies with schizophreniapatients. Schizophr. Bull. 8, 438-469.

Hashimoto, T., Kitamura, N., Kajimoto, Y., Shirai, Y., Shirakawa, O., Mita, T., Nishino, N., Tanaka, C., 1993. Differential changes in serotonin 5-HT1A and 5-HT2 receptor binding in patients with chronic schizophrenia. Psychopharmacology 112 (1 Suppl), S35-S39.

Heinz, A., Schlagenhauf, F., 2010. Dopaminergic dysfunction in schizophrenia: salience attribution revisited. Schizophr. Bull. 36, 472-485.

Javitt, D.C., 1987. Negative schizophrenic symptomatology and the PCP (phencyclidine) model of schizophrenia. Hillside J. Clin. Psychiatry 9 (1), 12-35.

Langen, B., Dost, R., Egerland, U., Stange, H., Hoefgen, N., 2012. Effect of PDE10A inhibitors on MK-801-induced immobility in the forced swim test. Psychopharmacology 221 (2), 249-259.

Livak, K.J., Schmittgen, T.D., 2001. Analysis of relative gene expression data using realtime quantitative PCR and the 2(-Delta Delta C(T)) method. Methods 25 (4), 402-408.

Malherbe, P., Masciadri, R., Norcross, R.D., Knoflach, F., Kratzeisen, C., Zenner, M.T., Kolb, Y., Marcuz, A., Huwyler, J., Nakagawa, T., Porter, R.H., Thomas, A.W., Wettstein, J.G., Sleight, A.J., Spooren, W., Prinssen, E.P., 2008. Characterization of (R,S)-5,7-di-tert-butyl-3-hydroxy-3-trifluoromethyl-3H-benzofuran-2-one as a positive allosteric modulator of GABAB receptors. Br. J. Pharmacol. 154 (4), 797-811.
Moghaddam, B., Jackson, M.E., 2003. Glutamatergic animal models of schizophrenia. Ann N YAcad Sci 1003, 131-137.

Munch-Petersen, S., 1955. Chlorpromazine ("Largactil") in the Management of Psychotic Patients. Acta Psychiatr. Neurol. Scand. 30, 643-658.

Noda, Y., Yamada, K., Furukawa, H., Nabeshima, T., 1995. Enhancement of immobility in a forced swimming test by subacute or repeated treatment with phencyclidine: a new model of schizophrenia. Br. J. Pharmacol. 116 (5), 2531-2537.

Noda, Y., Mamiya, T., Furukawa, H., Nabeshima, T., 1997. Effects of antidepressants on phencyclidine-induced enhancement of immobility in a forced swimming test in mice. Eur. J. Pharmacol. 324 (2-3), 135-140.

Noda, Y., Kamei, H., Mamiya, T., Furukawa, H., Nabeshima, T., 2000. Repeated phencyclidine treatment induces negative symptom-like behavior in forced swimming test in mice: imbalance of prefrontal serotonergic and dopaminergic functions. Neuropsychopharmacology 23 (4), 375-387.

Paine, T.A., Carlezon Jr., W.A., 2009. Effects of antipsychotic drugs on MK-801-induced attentional and motivational deficits in rats. Neuropharmacology 56 (4), 788-797.

Qiao, H., Noda, Y., Kamei, H., Nagai, T., Furukawa, H., Miura, H., Kayukawa, Y., Ohta, T., Nabeshima, T., 2001. Clozapine, but not haloperidol, reverses social behavior deficit in mice during withdrawal from chronic phencyclidine treatment. Neuroreport 12 (1), 11-15.

Samara, M.T., Dold, M., Gianatsi, M., Nikolakopoulou, A., Helfer, B., Salanti, G., Leucht, S., 2016. Efficacy, acceptability, and tolerability of antipsychotics in treatment-resistant schizophrenia: a network meta-analysis. JAMA Psychiat. 73 (3), 199-210.

Sumiyoshi, T., Stockmeier, C.A., Overholser, J.C., Dilley, G.E., Meltzer, H.Y., 1996. Serotonin1A receptors are increased in postmortem prefrontal cortex in schizophrenia. Brain Res. 708 (1-2), 209-214.

Thompson, R.M., Weickert, C.S., Wyatt, E., Webster, M.J., 2011. Decreased BDNF, trkBTK + and GAD67 mRNA expression in the hippocampus of individuals with schizophrenia and mood disorders. J. Psychiatry Neurosci. 36 (3), 195-203.

Tokarski, K., Zahorodna, A., Bobula, B., Hess, G., 2002. Comparison of the effects of 5 HT1A and 5-HT4 receptor activation on field potentials and epileptiform activity in rat hippocampus. Exp. Brain Res. 147 (4), 505-510.

Torrey, E.F., Barci, B.M., Webster, M.J., Bartko, J.J., Meador-Woodruff, J.H., Knable, M.B., 2005. Neurochemical markers for schizophrenia, bipolar disorder, and major depression in postmortem brains. Biol. Psychiatry 57 (3), 252-260.

Wierońska, J.M., Kusek, M., Tokarski, K., Wabno, J., Froestl, W., Pilc, A., 2011. The $\mathrm{GABA}_{\mathrm{B}}$ receptor agonist CGP44532 and the positive modulator GS39783 reverse some behavioural changes related to positive syndromes of psychosis in mice. Br. J. Pharmacol. 163 (5), 1034-1047.

Wierońska, J.M., Sławińska, A., Stachowicz, K., Łasoń-Tyburkiewicz, M., Gruca, P., Papp, M., Pilc, A., 2013. The reversal of cognitive, but not negative or positive symptoms of schizophrenia, by $\mathrm{mGlu}_{2 / 3}$ receptor agonist, LY379268, in $5-\mathrm{HT}_{1 \mathrm{~A}}$ dependent. Behav, Brain Res. 256, 298-304.

Wierońska, J.M., Sławińska, A., Łasoń-Tyburkiewicz, M., Gruca, P., Papp, M., Zorn, S.H., Doller, D., Kłeczek, N., Noworyta-Sokołowska, K., Gołembiowska, K., Pilc, A., 2015a. The antipsychotic-like effects in rodents of the positive allosteric modulator $\mathrm{Lu}$ AF21934 involve 5-HT1A receptor signaling: mechanistic studies. Psychopharmacology 232 (1), 259-273.

Wierońska, J.M., Kłeczek, N., Woźniak, M., Gruca, P., Łasoń-Tyburkiewicz, M., Papp, M., Brański, P., Burnat, G., Pilc, A., 2015b. mGlu5-GABA B $_{\text {interplay in animal models of }}$ positive, negative and cognitive symptoms of schizophrenia. Neurochem. Int. 88, 97-109.

Woźniak, M., Acher, F., Marciniak, M., Lasoń-Tyburkiewicz, M., Gruca, P., Papp, M., Pilc, A., Wierońska, J.M., 2016. Involvement of GABAB receptor signaling in antipsychotic-like action of the novel orthosteric agonist of the mGlu4 receptor, LSP42022. Curr. Neuropharmacol. 14 (5), 413-426.

Woźniak, M., Gołembiowska, K., Noworyta-Sokołowska, K., Acher, F., Cieślik, P., Kusek, M., Tokarski, K., Pilc, A., Wierońska, J.M., 2017. Neurochemical and behavioral studies on the $5-\mathrm{HT}_{1 \mathrm{~A}}$-dependent antipsychotic action of the mGlu $\mathrm{u}_{4}$ receptor agonist LSP4-2022. Neuropharmacology 115, 149-165. 